\title{
電気化学ノイズ法を用いた表面に黒皮が存在する 炭素鋼の腐食挙動の検討*
}

\author{
板垣昌幸**，蝦名晋太郎**，渡辺邦洋**，額賀孝訓***，梅村文夫*** \\ ***東京理科大学 理工学部 工業化学科 \\ *** 東京電力株式会社 技術開発研究所 材料技術グループ
}

\author{
Electrochemical Noise Analysis on Corrosion Behavior of \\ Carbon Steel Covered with Mill Scale * \\ Masayuki Itagaki**, Shintaro Ebina**, Kunihiro Watanabe**, \\ Takahiro Nukaga*** and Fumio Umemura*** \\ ** Department of Pure Applied Chemistry, Faculty of Science and Technology, Tokyo University of Science \\ *** The Tokyo Electric Power Company, Research \& Development Center
}

\begin{abstract}
Corrosion diagnosis and the corrosion mechanism investigations of carbon steel covered with mill scale in distilled water and aqueous solution containing various component $\left(\mathrm{Cl}^{-}, \mathrm{SO}_{4}{ }^{2-}, \mathrm{HCO}_{3}{ }^{-}, \mathrm{SiO}_{2}\right)$ were performed by using ENA. It has been clarified that the corrosion patterns could be discriminated by the measurements of potential time series and that the effects of the water quality factor on the corrosion could be discussed. Bicarbonate ions whose concentration is less than $10 \mathrm{ppm}$ accelerate the corrosion of carbon steel covered with mill scale. Besides, the bicarbonate ions whose concentration is $100 \mathrm{ppm}$ stabilize the mill scale. In neutral solution, the dissolved silica accelerates the anode reaction of carbon steel. Contrary to this in alkaline solution, the dissolved silica gives the corrosion resistance to the carbon steel with covered with mill scale.
\end{abstract}

Keywords : ENA, carbon steel, fresh water, mill scale

1. 緒

言

化学プラント，水処理などの分野において実用化され ている腐食モニタリング法として, 分極抵抗法が挙げら れる. しかしながら分極抵抗法の基礎理論は全面腐食系 を対象としており，構造材の突発的な破損につながる局 部腐食系を対象とはしていない。局部腐食の発生に対し て有効な電気化学測定法として, 近年電気化学ノイズ法 (Electrochemical Noise Analysis, ENA) が注目されてい る. 電気化学ノイズ法は, 電極表面状態または反応速度 のゆらぎを電位及び電流の振動としてとらえる方法であ り，腐食モニタリング及び局部腐食発生機構の解明に最 も有効な手法と期待されている1，2)。腐食モニタリング を目的として，ノイズ抵抗法が検討されている3)-9). 例 えば Mansfeld ら ${ }^{3)}$ は, $\mathrm{NaCl}$ 溶液中での電位振動と電流 振動の振幅の比からノイズ抵抗を求め, 電気化学インピ 一ダンス法から求めた分極抵抗と一致するとことを示し た。一方，ENA は局部腐食の発生と進展をその場定量す るための有効な手段であり, ステンレス鋼の孔食萌芽発 生が電流スパイクノイズの出現と良い相関関係を持つこ とが報告されている10),11)。また井上ら ${ }^{12)}$ は逆設定法によ り, 電位ノイズから局部アノード電流を推定する方法を 開発しており，電位ノイズの定量的な取り扱いに成功し ている. 炭素鋼及び鉄電極の ENAによる研究もノイズ

$*$ 第 50 回材料と環境討論会 (琉球大学, 2003 年) で発表

** ₹ 278-8510 野田市山崎 2641（2641, Yamazaki, Noda, 278-8510 Japan)

*** † 230-8510 横浜市鶴見区江ヶ崎 4-1 (4-1, Egasaki, Tsurumi, Yokohama, 230-8510 Japan)
抵抗に関する報告13)-17) と孔食によるスパイクノイズに関 する報告18)-22) に分けられる．後者では酸化性環境で皮膜 を有する炭素鋼の皮膜破壊を検討しており，ENAは炭素 鋼の局部腐食発生の検知に有効であると考えられる.

炭素鋼は淡水用配管として用いられることが多く，圧 延加工時に生成する酸化皮膜である黒皮を除去せずにそ のまま施工することもある．従って淡水中での黒皮の安 定性を検討することも, 局部腐食研究の重要な課題の一 つとなる。淡水中には $\mathrm{Cl}^{-}, \mathrm{SO}_{4}{ }^{2-}, \mathrm{HCO}_{3}{ }^{-}, \mathrm{CO}_{3}{ }^{2-}$, $\mathrm{Mg}^{2+}, \mathrm{Ca}^{2+}, \mathrm{SiO}_{2}$ などの多様な成分種が溶存する。淡 水中での炭素鋼の腐食挙動を知るためには, 上述のイオ ンの影響とそれらの複合的な影響（相互作用，相乗作用） を調べることが重要となる．淡水中での炭素鋼の腐食に 関する研究は数多く行われている23)-25). 例えば藤井ら ${ }^{25)}$

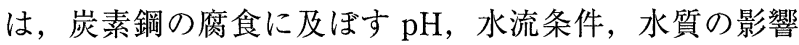
を詳細に検討している．保田ら ${ }^{26)}$ は，模擬冷却水中での 黒皮を表面に有する炭素鋼（以後黒皮付炭素鋼と呼ぶ） の腐食挙動を検討し，黑皮はカソード反応速度を加速す るため, $\mathrm{Cl}^{-}$や $\mathrm{SO}_{4}{ }^{2-}$ の腐食性イオンが存在すると欠陥部 から腐食が発生することを報告している.

本報では，黑皮付炭素鋼の局部腐食発生条件と水質の 関係を ENAにより解析する。具体的には淡水中に含ま れる溶存種の中で $\mathrm{HCO}_{3}{ }^{-}, \mathrm{SiO}_{2}, \mathrm{Cl}^{-}, \mathrm{SO}_{4}{ }^{2-}$ に焦点を当て, 黒皮付炭素鋼の腐食に与える影響を検討する，炭素鋼に 関するスパイクノイズの解析では，すべての文献18)-20)に おいて酸化処理を行い生成した皮膜の崩壊を取り扱って いる，本報では，黒皮付炭素鋼を用いることにより，あ りのままの表面状態での炭素鋼の腐食挙動を ENAによ り検討する。さらに, GD-OES (Glow Discharge Optical Emission Spectroscopy) を用いた元素分布分析を補助的 
Table 1 Chemical composition of the carbon steel covered with mill scale.

\begin{tabular}{|c|c|c|c|c|c|}
\hline element & $\mathrm{C}$ & $\mathrm{Si}$ & $\mathrm{Mn}$ & $\mathrm{P}$ & $\mathrm{S}$ \\
\hline content $\times 100[\mathrm{wt} \%]$ & 4 & 3 & 14 & 2.2 & 0.5 \\
\hline
\end{tabular}

に用い，炭素鋼表面に存在する黒皮の安定性を考察する。

\section{2. 実 験 方 法}

\section{1 試 験 片}

試験片には，黒皮の付いた炭素鋼（JIS, G 3131 SPHC） の板を用いた，本報で用いた炭素鋼は，単一の鋼板から 切り出し，ほほ同様の組成の黒皮を表面に有している. 実験により表面を研磨し黒皮を取り除いた試験片も使用 した。試験片の化学的組成を Table 1 に示す。

\section{2 分 極曲 線}

分極曲線の測定は 3 電極法で行った。対極には白金線 を，参照極には飽和塩化銀/銀電極 $(\mathrm{SSE})$ を用いた，以 後本報における電位は SSE 基準とする. 分極曲線の測定 では，作用極に炭素鋼及び黒皮付炭素鋼を用いた。作用 極は暴露面以外を電着塗装しエポキシ系樹脂で固めさら にその上をシリコン系樹脂で覆うことにより作成した。 炭素鋼の研磨はエメリー紙 2000 番まで行い, 測定前に はメタノールと蒸留水で洗浄を行った. 作用極面積は 1 $\mathrm{cm}^{2}$ とした. 浸漬電位から電位を $100 \mathrm{mV} / \mathrm{min}$ の走査速 度でアノード及びカソード方向へ電位を挿引し, 応答電 流を記録した。測定溶液として $100 \mathrm{ppm}$ の $\mathrm{HCO}_{3}{ }^{-}$及び, $1 \mathrm{ppm}$ の $\mathrm{SO}_{4}{ }^{2-}$ を含む水溶液を用いた．またアノード分 極曲線測定前には窒素ガスをバブリングすることで溶液 の脱酸素を行った。一方, カソード分極曲線は, 大気飽 和条件での溶液を用いて行った。

\section{3 電位経時変化測定}

電位経時変化の測定は 2 電極法で行った。試験片には 特別な前処理を行わず，黒皮が付いた炭素鋼表面を作用 極として用いた。作用極面積は $1 \mathrm{~cm}^{2}$ とした. 暴露面以 外に電着塗装を施し, さらにその上をシリコン系樹脂で 覆った．参照極として SSE を用いた。

蒸留水, 試薬特級の $\mathrm{NaOH}, \mathrm{NaHCO}_{3}, \mathrm{NaCl}, \mathrm{Na}_{2} \mathrm{SO}_{4}$, (以上和光純薬製) 及び非晶質 $\mathrm{SiO}_{2}$ (関東化学製) を用い て試験溶液を調製した。 $\mathrm{SiO}_{2}$ 溶液の調製手順 27), 28) は以 下である. 始めにビーカーに $1 \mathrm{dm}^{3}$ 程度の蒸留水を入れ $0.2 \mathrm{~g}$ の非晶質 $\mathrm{SiO}_{2}$ を加えた. その後オーブン/電子レン ジ（SHARP 製，RE-LA1）を用いて 12 時間 $270^{\circ} \mathrm{C} て ゙$ 加熱 し $\mathrm{SiO}_{2}$ を溶解した. 冷却後, 万紙を用いて溶液をろ過し た. ろ液中に含まれるモノマーの $\mathrm{SiO}_{2}$ 濃度はモリブデン イエロー法（JIS, K 0101）により決定した．ろ液を任意の 濃度に希釈し試験溶液とした。試験溶液の温度は $30^{\circ} \mathrm{C}$ と した。

自然電位の測定には $6 \mathrm{ch}$ エレクトロメータ（北斗電工 製，HE-105A）を用いた。得られた測定データを A/D コ ンバータ（キーエンス製，GR-3500）を介しパーソナルコ
ンピュータへと転送・保存した。データのサンプリング 時間は 1 秒とした。電位経時変化測定後，レーザー顕微 鏡を用いて作用極表面の観察を行った。また電位経時変 化の測定時には，表面分析用の試験片を同時に浸漬させ た。この試験片を任意の時間に取り出し, GD-OES（堀 場製作所製 JY-5000RF）を用いて表面分析を行った. GD-OES により試験片表面からの各元素の深さ方向分布 を調べた。

\section{3. 結果および考察}

\section{1 黒皮の組成分析}

黒皮とは鉄鋼用語であり，JIS（日本工業規格）におい て「鋳放し状態の表面」29)もしくは「鍛造したままの鍛 造品の肌」30）として定義されている．すなわち圧延加工 時に生成した鉄酸化皮膜のことをさす。添野ら 31 ) は高 $\mathrm{Cr}$ 圧延ロール上に生ずる黒皮の主成分は $\mathrm{Fe}_{3} \mathrm{O}_{4}$ であると 報告している．また黄ら ${ }^{32)}$ は高速度鋼ロールにより生成 する黒皮を XRD 及び EDS などの表面分析を用いて解析 し，黒皮が酸素を多く含む鉄酸化物であり主な組成層が $\mathrm{Fe}_{3} \mathrm{O}_{4}$ であること，黒皮上に存在する金属炭化物に沿っ てクラックが成長することを報告している．本論文で用 いた黒皮も微視的なクラックを有するものと考えられる.

本実験で用いた黒皮付炭素鋼の GD-OESによる分析 結果（分析元素 : Fe, C, O, Si）を Fig. 1 に示す．縦軸は任 意の発光強度であり，元素ごとにその感度が異なる．横 軸はスパッタリング時間であり， $1 \mathrm{~s}$ が約 $0.21 \mu \mathrm{m}$ のスパ ッタリングに相当する。ただし黒皮上には凹凸が存在す るため，このスパッタリング深さは平均的な情報である. 本来ならば横軸をスパッタリング深さで記すべきである が，スパッタリング速度は組成に依存し変化するので, 正確を期するためにスパッタリング時間にて表記した。 $\mathrm{Fe}$ の発光強度は，0 $\mathrm{s}$ からスパッ夕時間と共に増加し，5 $\mathrm{s}$ 付近で飽和值となった。 Cの発光強度は表面近傍が非 常に大きくその後指数関数的に減少している. Si の発光 強度も表面近傍が大きくその後指数関数的に減少してい る．Ｏの検出感度は悪いが，表面近くで比較的大きな発 光強度を示している．以上のことからスパッ夕時間 $5 \mathrm{~s}$ までが黒皮部, それ以降は下地の炭素鋼部であったと考

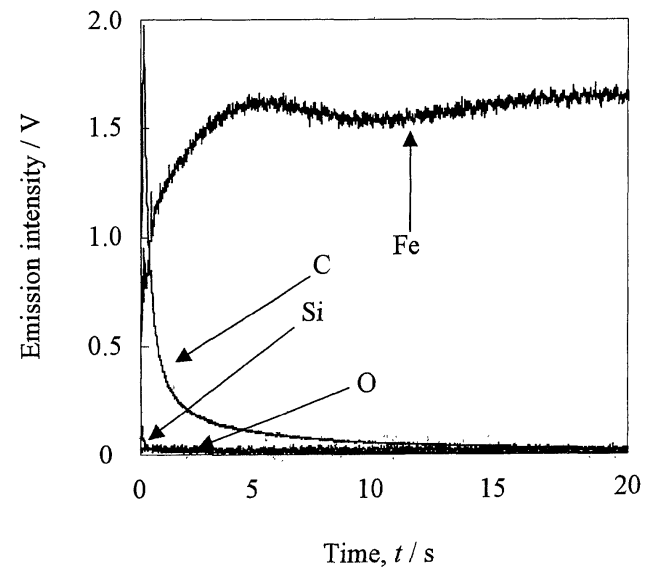

Fig. 1 Depth profiles of Fe, C, Si and O in carbon steel with mill scale measured by GD-OES. 


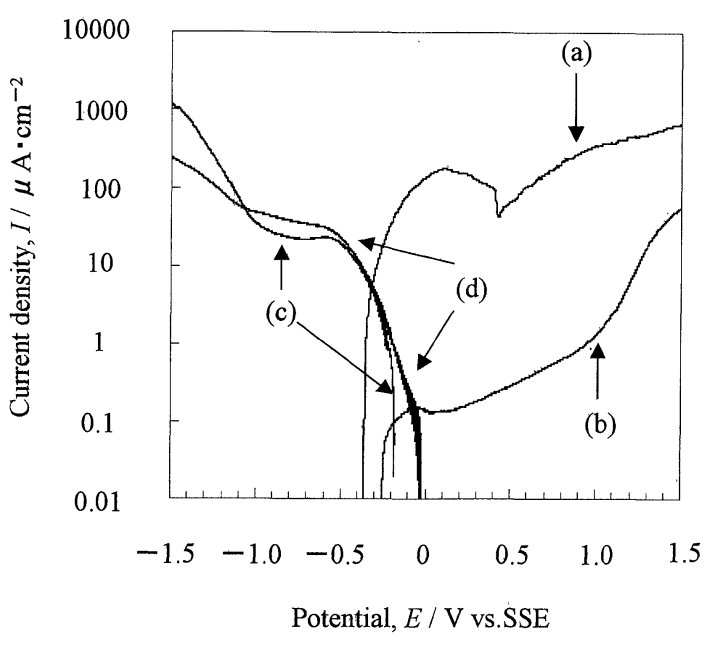

Fig. 2 Polarization curves of carbon steel and carbon steel with mill scale in the solution containing $100 \mathrm{ppm} \mathrm{HCO}_{3}{ }^{-}$and 1 $\mathrm{ppm} \mathrm{SO}_{4}{ }^{2-}(\mathrm{pH}=8.3)$. The anodic and cathodic polarization curves were measured in deaerated and air-saturated solutions, respectively. (a): anodic polarization curve of carbon steel, (b): anodic polarization curve of carbon steel with mill scale, (c): cathodic polarization curve of carbon steel, and $(\mathrm{d})$ : cathodic polarization curve of carbon steel with mill scale.

えられる，以上より，本研究で用いた黒皮の厚さはおお よそ $1 \mu \mathrm{m}$ 程度であることがわかる.

\section{2 分極曲線測定}

$100 \mathrm{ppm}$ の $\mathrm{HCO}_{3}{ }^{-}$及び $1 \mathrm{ppm}$ の $\mathrm{SO}_{4}{ }^{2-}$ を含む溶液中で の炭素鋼, 黒皮付炭素鋼のアノード分極曲線とカソード 分極曲線を Fig. 2 に示す. 炭素鋼のアノード分極曲線に おいて, 約 $-0.37 \mathrm{~V} よ り$ 貴な電位で活性溶解による大き な電流が流れている. 一方, 黒皮付炭素鋼のアノード分 極曲線では, 約 $-0.27 \mathrm{~V} よ り$ 貴な電位で微小なアノード 電流が流れている. 例えば $0 \mathrm{~V} て ゙$ 比較すると，炭素鋼の アノード電流は黒皮付炭素鋼のものと比較して 3 桁程度 大きく，この結果は黒皮の鉄活性溶解に対する保護作用 を示している．また，大気飽和溶液中での炭素鋼のカソ ード分極曲線において, 約 $-0.2 \mathrm{~V}$ より卑な電位で酸素還 元によるカソード電流が流れている，一方，黒皮付炭素 鋼では， $-0.03 \mathrm{~V} よ り$ 卑な電位からカソード電流が流れ ている. 黒皮付炭素鋼のカソード電流がより貴な電位か ら流れるのは, 黒皮自体の還元電流が酸素還元によるカ ソード電流に上乗せされること, または黒皮により酸素 の還元速度が加速されること ${ }^{26)}$ による.ここで，アノー ド分極曲線とカソード分極曲線の交点を腐食系における 混成電位とみなす，炭素鋼及び黒皮付炭素鋼の混成電位

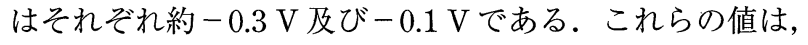
炭素鋼表面に黒皮を有する場合の自然電位が大きく貴な 值となることを示し, 自然電位の測定が黒皮による保護 性を判断する基準となることを意味する.

\section{3 電位経時変化}

\subsection{1 蒸留水及び希薄 $\mathrm{NaOH}$ 溶液中での浸漬試験結果}

蒸留水 $(\mathrm{pH}=5.4)$ 及び $\mathrm{NaOH}$ を用いて $\mathrm{pH}$ を 9 に調整 した溶液中に浸漬した黒皮付炭素鋼の電位経時変化を

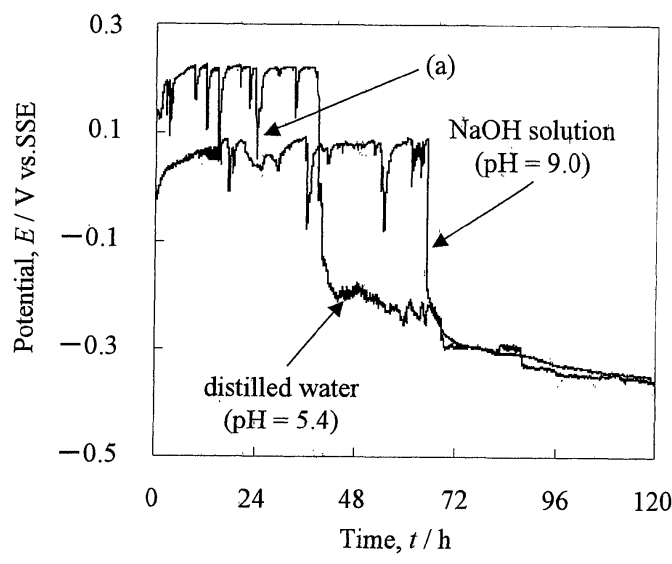

Fig. 3 Potential time series of carbon steel covered with mill scale in distilled water $(\mathrm{pH}=5.4)$ and $\mathrm{NaOH}$ solution $(\mathrm{pH}=9.0)$. The zoom up of spike noise indicated by $(\mathrm{a})$ is shown in Fig. 4.

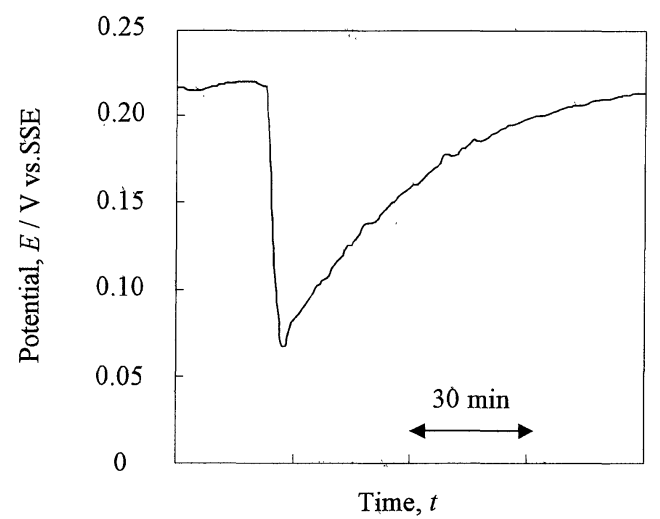

Fig. 4 Typical potential spikenoise of carbon steel covered with mill scale in distilled water.

Fig. 3 に示す。蒸留水中に扔ける黒皮付炭素鋼の電位は 浸漬後に約 $0.2 \mathrm{~V}$ に停滞しながらスパイク状の電気化学 ノイズを示した後，約 40 時間の浸漬時間を経て急激な 電位卑化を示した. Fig. 3 中に（a）で示した電位スパイ ク (浸漬約 15 時間後) の拡大図を Fig. 4 に示す。電位が 急激に卑に移行した後に，緩やかに回復している。この タイプの電位ノイズは, RD (Rapid Drop followed by Slow Recovery）型ノイズと呼ばれる.一般的に， RD 型ノイズ は酸化性環境における皮膜の破壊および再生に対応して 発生する ${ }^{33)-35)}$. 本実験では，黒皮の破壊及び酸化皮膜の 再生が RD 型ノイズの発生原因となる。すなわち，黒皮 の破壊が瞬時に起きるのに対し, 酸化皮膜生成反応が炭 素鋼の溶解反応との競争反応となり, 皮膜生成のための 時間が比較的大きくなる．板垣ら ${ }^{36)}$ はチャンネルフロー 電極法とレーザーインパクト法を組み合わせ，硫酸溶液 中での鉄酸化物皮膜の破壊とその再生機構について報告 しでいる。レーザーインパクトにより酸化皮膜が破壊さ れると鉄の新生面が溶液中に露出し, その界面で $\mathrm{Fe}$ (II) の溶解反応と皮膜再生反応が起こる. それぞれの反応速 度に依存して, 皮膜再生時間は溶液の $\mathrm{pH}$ と電極電位の 関数となる。この報告 ${ }^{36)}$ は本論文における皮膜再生反応 と定性的に一致している. 一方， $\mathrm{pH}$ を 9.0 に調整した溶 


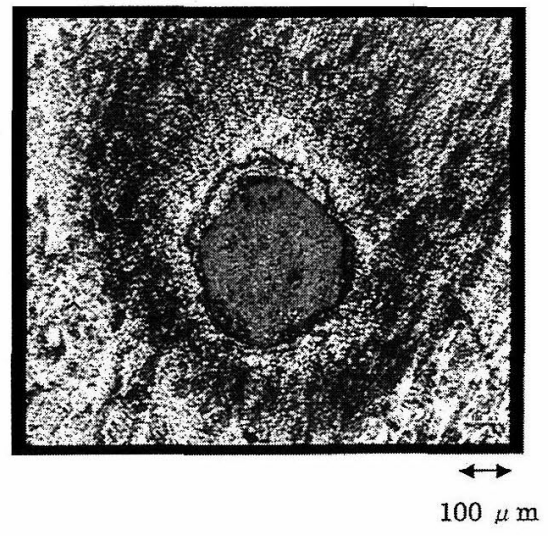

Fig. 5 Laser microscope photograph of specimen surface after the measurement of potential time series in distilled water, which are presented in Fig. 3.

液中においては，電位卑化までの誘導時間が大きくなっ た。この結果は， $\mathrm{pH}$ が大きいと鉄酸化物が熱力学的に 安定であり，鉄の溶解反応に対して皮膜再生反応速度が 相対的に大きくなるためである。

浸漬試験後の電極の表面観察をレーザー顕微鏡により 行った結果，電極表面には食孔がいくつか確認された。 典型的な食孔のレーザー顕微鏡写真を Fig. 5 に示す。こ の食孔の直径は約 $450 \mu \mathrm{m}$ ，媣さは $70 \mu \mathrm{m}$ 程度であった。 浸漬試験後の作用極表面には Fig. 5 に示したような食孔 が数個確認されたが電位スパイクノイズの数よりも食孔 の数は少なかった。これはある食孔に扔いて皮膜の破壊 掠よび再生が複数回生じていたことを示唆している．孔 食が確認されたことは八ロゲン化物イオンなどの攻撃性 アニオンが存在しない溶液中においても，黒皮付炭素鋼 は局部腐食を生ずることを意味する．溶液中に $\mathrm{Cl}^{-}$など の攻撃性アニオンが含まれていないにも関わらず，黒皮 付炭素鋼において局部腐食が発生したのは, 黒皮には微 細なクラックが存在し，その火陥部から水が浸透するこ とによるものと考学れれ。.

\subsection{2 $\mathrm{HCO}_{3}$-溶液中での浸清試験結果}

$\mathrm{HCO}_{3}$-をそれぞれ $1,10,100 \mathrm{ppm}$ 命む溶液中に黒皮付 炭素鋼を浸漬させたときの電位経時変化を Fig. 6 に示す. すべての溶液の $\mathrm{pH}$ を 8.4 に調整した. $1 \mathrm{ppm}$ の $\mathrm{HCO}_{3}$ を含む溶液中においては，浸漬直後から電位は卑に移行 し，自然電位は浸漬 72 時間後には約 $-0.58 \mathrm{~V}$ となり，そ の後に安定した．浸漬試験後の試験片表面には，全面的 に腐食の痕跡が観察された。 $10 \mathrm{ppm} の \mathrm{HCO}_{3}$-を含む溶 液中においては, 浸漬後 20 時間程度の間, 電位は一定 であり皮膜が安定に存在したことを意味する。しかし浸 漬約 24 時間を過ぎると $\mathrm{RD}$ 型ノイズが発生した後, 急激 に電位が卑に移行した。浸漬試験後の試験片表面には, 食孔が確認できた. 試薬溶解時の $\mathrm{HCO}_{3}$-を $100 \mathrm{ppm}$ 含 む溶液中においては, 自然電位は浸漬試験を通じてほほ 一定であり浸漬試験後の試験片表面には腐食跡は見られ ず皮膜が安定に存在していた。すなわち本測定では， $\left[\mathrm{HCO}_{3}{ }^{-}\right]$が $1 \mathrm{ppm}$ の場合は活性溶解を示し, $10 \mathrm{ppm}$ で は局部腐食が発生し，100 ppm では皮膜は健全に存在し ていた。 以上のことから $\mathrm{HCO}_{3}$-は低濃度では皮膜溶解の 促進, 高濃度では皮膜の保持に対して効果を持つことが

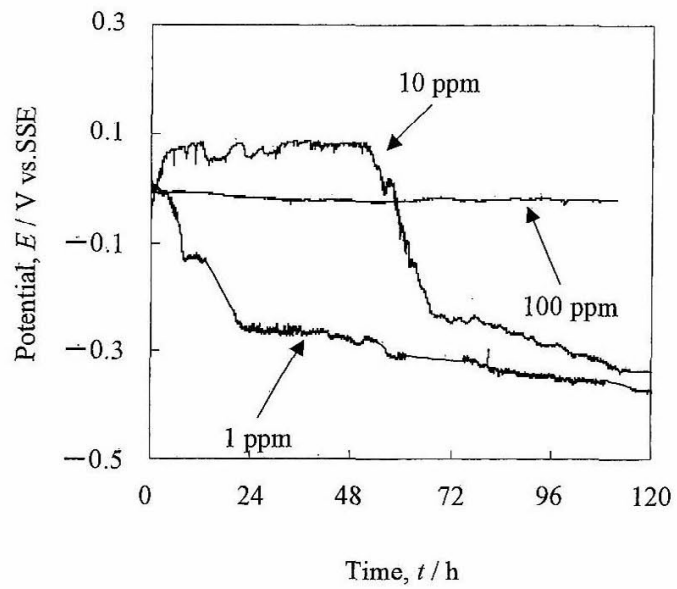

Fig. 6 Potential time series of carbon steel covered with mill scale in 1,10 , and $100 \mathrm{ppm} \mathrm{HCO}_{3}^{-}$solutions $(\mathrm{pH}=8.4)$.

示唆される. Davies ら ${ }^{37)}$ は重炭酸イオンを含む溶液中で の $\mathrm{Fe}$ のアノード反応機構を解析し, $\mathrm{Fe}$ は $\mathrm{Fe}\left(\mathrm{CO}_{3}\right)_{2}{ }^{2-}$ と して溶解することを報告した。 さらにCastro ら ${ }^{38)} も$ ， さまざまな濃度の炭酸/重炭酸イオンを含む溶液中で Fe が活性溶解を示すことを報告している．以上から，重炭 酸イオンは鉄活性溶解を促進する効果を持ち, 重炭酸イ オン濃度が小さい場合に扔いて腐食が生じたのものだと 考えられる。

以上とは対照的に, Videm ら ${ }^{39)}$ は分極曲線の測定から， 溶液中の $\mathrm{NaHCO}_{3}$ 濃度が大きくなるにつれ不働態保持電 流が減少し不働態化電位が卑に移行することを報告して いる. 春名ら ${ }^{40)}$ は, 重炭酸イオンが存在する溶液中にお ける岸素鋼の電位- $\mathrm{pH}$ 図を作成した. 春名ら40)によれば, $\mathrm{pH}$ が 8.4 の重炭酸イオン溶液中に扔いて鉄の安定な生成 物は $\mathrm{FeCO}_{3}, \mathrm{Fe}_{2} \mathrm{O}_{3}$ 及び $\mathrm{Fe}(\mathrm{OH})_{3}$ である。板垣ら 27) は, GD-OES を用いた表面深さ元素分析を行い，重炭酸イオ ン溶液中で生成する皮膜は $\mathrm{FeCO}_{3}$ を経由して生成する $\mathrm{Fe}_{2} \mathrm{O}_{3}$ や $\mathrm{Fe}_{3} \mathrm{O}_{4}$ などの高次酸化物であると述べている. 以上より，本測定において重炭酸イオン濃度が $100 \mathrm{ppm}$ の場合は，黑皮久陷部に高次酸化物が生成し，耐食性を 示したと考えられる。

\subsection{3 $\mathrm{SiO}_{2}$ 溶液中での浸漬試験結果}

溶性シリカを 10 及び $100 \mathrm{ppm}$ 含む溶液中に黒皮付炭 素銅を浸漬させたときの電位絟時変化を Fig. 7 に示す. な㧍, 各溶液の $\mathrm{pH}$ は $10 \mathrm{ppm} \mathrm{SiO}_{2}$ では $6.1,100 \mathrm{ppm} \mathrm{SiO}_{2}$ では 7.0 であった. 溶性シリカ濃度が 10 及び $100 \mathrm{ppm} の$ いずれの場合も自然電位は浸漬直後から㫗に移行してお り, $100 \mathrm{ppm} \mathrm{SiO}_{2}$ の場合にその傾向が顕著である. また 試験後の作用極表面には，どちらの場合にも全面的な腐 食の痕跡が確認された。 これらの結果は, 中性溶液では, $\mathrm{SiO}_{2}$ は黒皮付炭素鋼に対して保護性を付与せず，逆に腐 食を促進することを意味する。

さらに, $\mathrm{pH}$ を 9.0 に調整した $100 \mathrm{ppm} \mathrm{SiO}_{2}$ 溶液中で の電位経時変化も Fig. 7 に示す. pH が 9.0 の溶液中にお いて, 黑皮付炭素鋼の電位は浸漬直後から貴に移行した。 また浸漬試験後に行ったレーザー顕微鏡による観察で は，作用極表面に腐食は確認されれなかった。一般的に， 溶性シリカは $\mathrm{pH} に よ り$ 存在形態が変化するといわ机て 


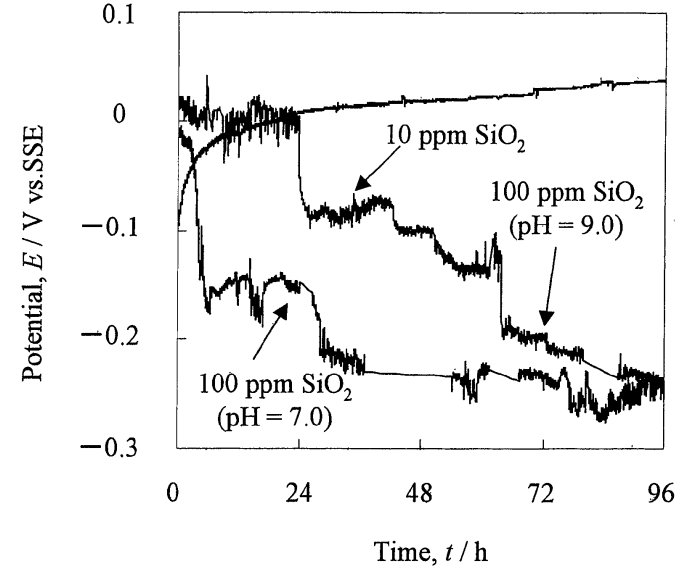

Fig. 7 Potential time series of carbon steel covered with mill scale in $10,100 \mathrm{ppm} \mathrm{SiO}_{2}$ solutions $(10 \mathrm{ppm}: \mathrm{pH}=6.1$, $100 \mathrm{ppm}: \mathrm{pH}=7.0)$, and $100 \mathrm{ppm} \mathrm{SiO}_{2}$ solution whose $\mathrm{pH}$ was adjusted to 9.0 by $\mathrm{NaOH}$.

いる. Lahondny-Sarc ら ${ }^{41)}$ は $\mathrm{SiO}_{2}$ を含む溶液中での $\mathrm{Fe}$ の溶解挙動に与える $\mathrm{pH}$ の影響を分極曲線の測定により 検討し, $\mathrm{pH}$ の上昇により不働態保持電流が低下するこ

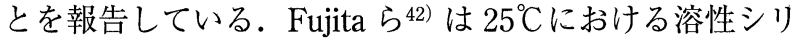
力の平衡図を描き, $\mathrm{pH}$ が 4 7では溶性シリカは $\mathrm{H}_{2} \mathrm{SiO}_{3}$ の状態で存在し, $\mathrm{pH}$ が 9 付近となると $\mathrm{H}_{2} \mathrm{SiO}_{3}$ もしくは $\mathrm{HSiO}_{3}{ }^{-}$の形で存在すると報告している，上記の報告及び 本実験の結果から $\mathrm{SiO}_{2}$ 溶液中での黒皮付炭素鋼の腐食挙 動には $\mathrm{pH}$ による溶性シリカの存在状態が大きく関わっ ていると考えられる.すなわち, 弱酸性から中性の溶液 中では溶性シリカは電荷を持たない分子であるため黒皮 に対して保護性を与えないが，pH が大きくなると $\mathrm{HSiO}_{3}$-または $\mathrm{Si}_{2} \mathrm{O}_{5}{ }^{2}$-などのイオン状の形態をとるため, 密着性のある良い $\mathrm{Si}$ 化合物皮膜が生成し黒皮を補修する。

$100 \mathrm{ppm} \mathrm{SiO}_{2}$ 溶液 $(\mathrm{pH}=9.0)$ に浸漬させた黒皮付炭素 鋼の黒皮に含まれる $\mathrm{Si}$ の存在量の GD-OES による分析 結果を Fig. 8 に示す. 電位経時変化測定時に GD-OES 測 定用黒皮付炭素鋼を試験溶液に同時に浸漬させ，任意の 時間（30, 60, 70 時間）に試験片を取り出し，GD-OES 測 定を行った。Fig. 8 において, 浸漬時間の増加と共に Si

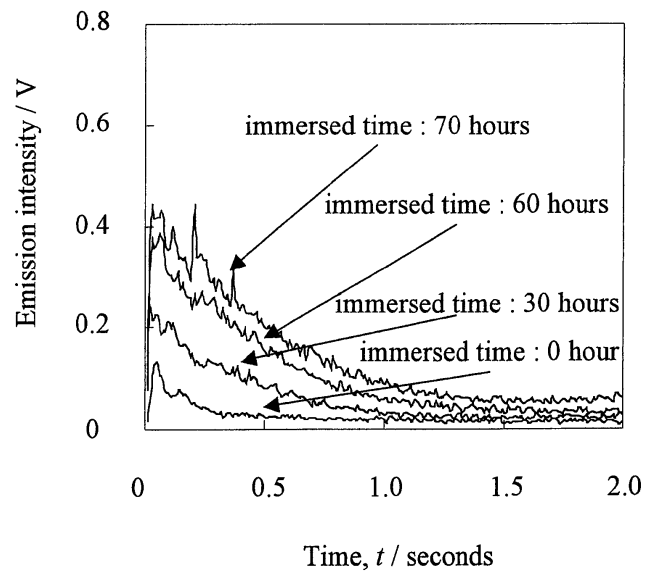

Fig. 8 Depth profile of $\mathrm{Si}$ in carbon steel covered with mill scale immersed in $100 \mathrm{ppm} \mathrm{SiO}_{2}$ solutions.
の発光強度は相対的に大きくなっている．このことから 浸漬時間が増加すると表面または皮膜内部の $\mathrm{Si}$ の存在量 が増加することがわかる．Fujita ら 42 はシリカと溶解し た Fe が反応し $\mathrm{Fe}$ または Fe 酸化物上に緻密な不溶性の $\mathrm{Si}$ 化合物が生成することにより耐食性が増すと説明して おり，本報の結果とも一致している.

\subsection{4 攻撃性アニオン $\left(\mathrm{Cl}^{-}, \mathrm{SO}_{4}{ }^{2-}\right)$ を含む溶液中での 浸漬試験結果}

$1,10,100 \mathrm{ppm}$ の $\mathrm{Cl}^{-}$を含む溶液中に黒皮付炭素鋼を浸 漬させた時の電位経時変化を Fig. 9 に示す. 蒸留水及び $\mathrm{NaOH}$ 溶液中（Fig. 3) とは異なり浸漬直後から自然電位 は卑に移行し， $\mathrm{Cl}^{-}$の濃度が大きくなるほど腐食電位は 卑となった。試験後の試験片表面はいずれも全面腐食状 となっていた，1,10,100 $\mathrm{ppm} \mathrm{SO}_{4}{ }^{2-}$ を含む溶液中に黒皮 付炭素鋼を浸漬させたときの電位経時変化を Fig. 10 に示 す. $\mathrm{SO}_{4}{ }^{2-}$ 濃度が $1 \mathrm{ppm}$ の時, 浸漬直後に $\mathrm{RD}$ 型の電気 化学ノイズを発生しながら電位は卑下した. $\mathrm{SO}_{4}{ }^{2-}$ 濃度 が $10 \mathrm{ppm}$ 以上の溶液中では浸漬直後から電位は卑に移 行している。また $\mathrm{Cl}^{-}$を含む溶液中と同様に $\mathrm{SO}_{4}{ }^{2-}$ 濃度

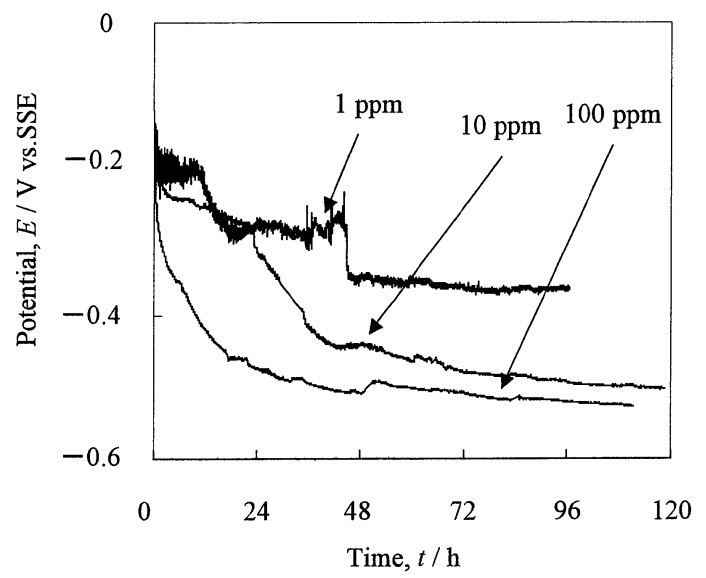

Fig. 9 Potential time series of carbon steel covered with mill scale in aqueous solutions containing 1,10 , and $100 \mathrm{ppm}$ $\mathrm{Cl}^{-}(1 \mathrm{ppm}: \mathrm{pH}=5.4,10 \mathrm{ppm}: \mathrm{pH}=5.4,100 \mathrm{ppm}: \mathrm{pH}=$ $5.3)$.

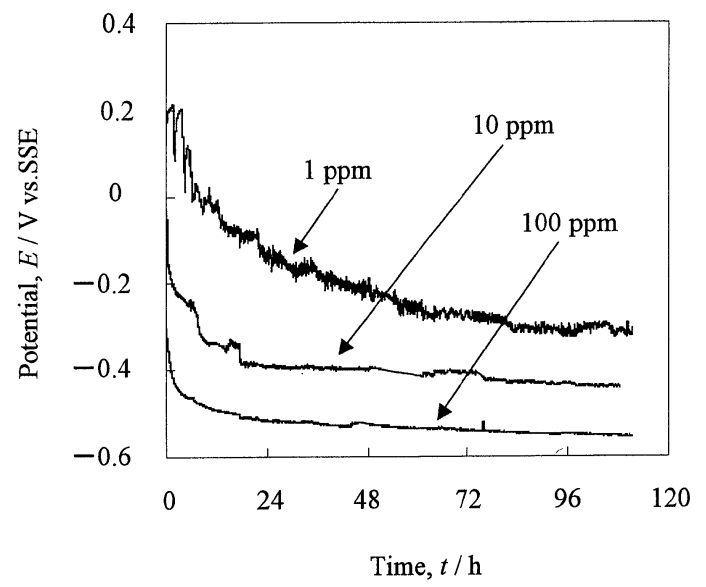

Fig. 10 Potential transient behaviors of carbon steel covered with mill scale in aqueous solutions containing $1,10,100$ ppm $\mathrm{SO}_{4}{ }^{2-}(1 \mathrm{ppm}: \mathrm{pH}=5.4,10 \mathrm{ppm}: \mathrm{pH}=5.4,100$ $\mathrm{ppm}: \mathrm{pH}=5.2$ ) 
が増大するにつれ腐食電位は卑に移行した。試験後の試 験片表面には, 不均一に進行した腐食が全面に確認され た. Fig. 9 及び Fig. 10 に示した電位経時変化に対して FFT を行い得たパワースペクトル密度を Fig. 11 に示す。 両結果共に, パワースペクトル密度は周波数に依存して 減少しており，その傾きは-1 から-2 の間の值をとっ ている。一般的に，パワースペクトル密度と周波数の対 数との関係において傾きが急になるほど相関性があると いわれている.Cui ら ${ }^{43)}$ はSRET(Scanning Reference Electrode Technique) 測定により，炭素鋼表面電位 2 次 元分布を測定し, $\mathrm{Cl}^{-}$または $\mathrm{SO}_{4}{ }^{2-}$ を含む溶液中で炭素鋼 上の活性 (低電位) サイトが時間により位置を変えるこ とを見い出した。これは，塩化物イオンなどの攻撃性ア ニオンが存在する場合, 活性 (局部腐食) サイトの移動 により炭素鋼の全面腐食が生ずることを意味する。電位 経時変化及び電極表面観察から, $\mathrm{SO}_{4}{ }^{2-}$ 存在下では黒皮 付炭素鋼は表面上の至る所に局部腐食が生じ，最終的に 全面腐食に至ることがわかった，さらに，Fig. 11 に示し たパワースペクトル密度の検討により複数の活性サイト の相互作用を検討できる可能性がある.

\subsection{5 $\mathrm{HCO}_{3}{ }^{-}$溶液に攻撃性アニオン $\left(\mathrm{Cl}^{-}, \mathrm{SO}_{4}{ }^{2-}\right)$ を 加えた溶液中での浸清試験結果}

$\mathrm{HCO}_{3}{ }^{-を} 100 \mathrm{ppm}$ 及び $\mathrm{Cl}^{-を} 1,10,100 \mathrm{ppm}$ 含む溶液 中に黒皮付炭素鋼を浸漬させた時の電位経時変化を Fig.
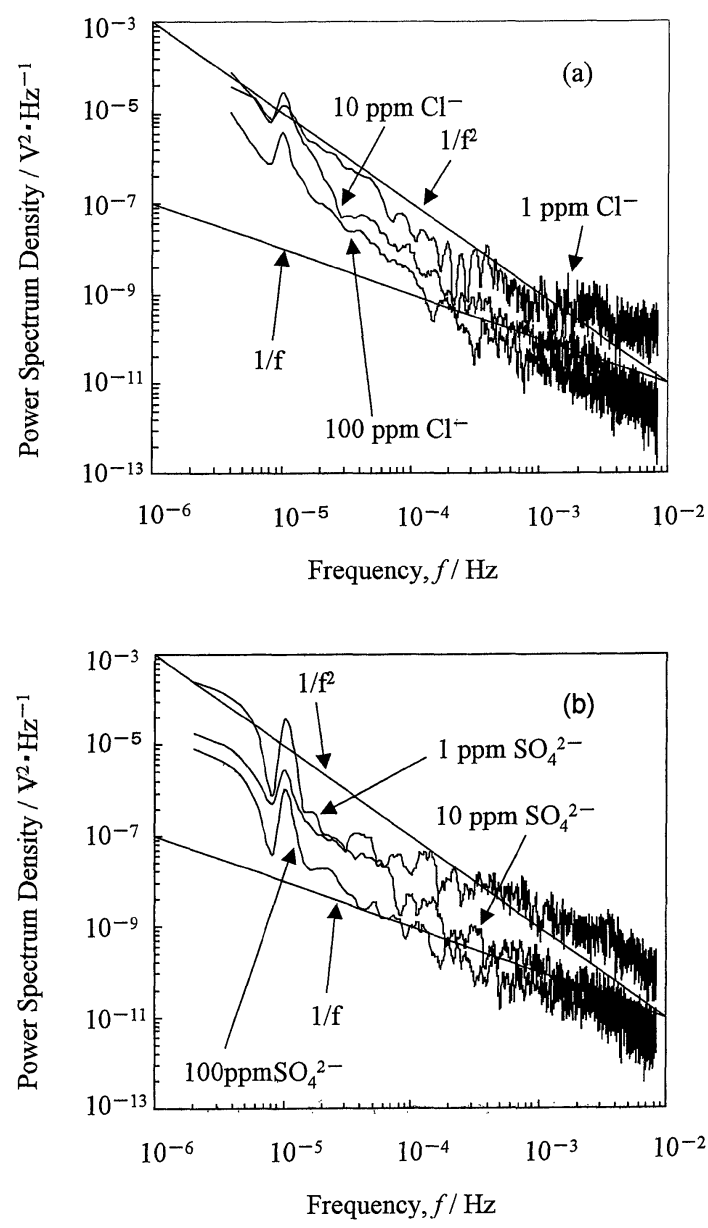

Fig. 11 Power spectrum densities calculated by FFT form the time series presented in (a) Fig. 9 and (b) Fig. 10.
12 に示す. $\left[\mathrm{Cl}^{-}\right]=1 \mathrm{ppm}$ の場合, 電位は浸漬直後から 約 $0 \mathrm{~V}$ (vs.SSE) で安定した。試験後の作用極表面には腐 食は見られなかった。 $\left[\mathrm{Cl}^{-}\right]=10 \mathrm{ppm}$ の場合, 浸漬数時 間で $\mathrm{RD}$ 型ノイズが発生し, 70 時間経過後電位は急激に 卑に移行した. $\left[\mathrm{Cl}^{-}\right]=100 \mathrm{ppm}$ となると浸漬直後から 電位は卑に移行した。試験後の作用極表面は $1 \mathrm{ppm}$ では 皮膜が健全に存在し，10 ppm では孔食が確認でき，100 ppmでは全面的に腐食が進行していた。

$\mathrm{HCO}_{3}{ }^{-}$を $100 \mathrm{ppm}$ ，及び $\mathrm{SO}_{4}{ }^{2-}$ を $1,10,100 \mathrm{ppm}$ 含む溶 液中に黒皮付炭素鋼を浸漬させた時の電位経時変化を Fig. 13 に示す. $\left[\mathrm{SO}_{4}{ }^{2-}\right]=1 \mathrm{ppm}$ の場合, 浸漬 17 時間で 最初の電気化学ノイズが発生した. その後も数本の電気 化学ノイズが確認され, 浸漬 108 時間以降急激に電位は 卑下した。 $\left[\mathrm{SO}_{4}{ }^{2-}\right]=10 \mathrm{ppm}$ 以上となると浸漬後電位は 卑に移行した。以上の結果から重炭酸イオンを含む腐食 抑制性の溶液中では $\mathrm{SO}_{4}{ }^{2-}$ が $\mathrm{Cl}^{-}$よりも黒皮付炭素鋼の 腐食に対する影響が大きいものと考えられる。

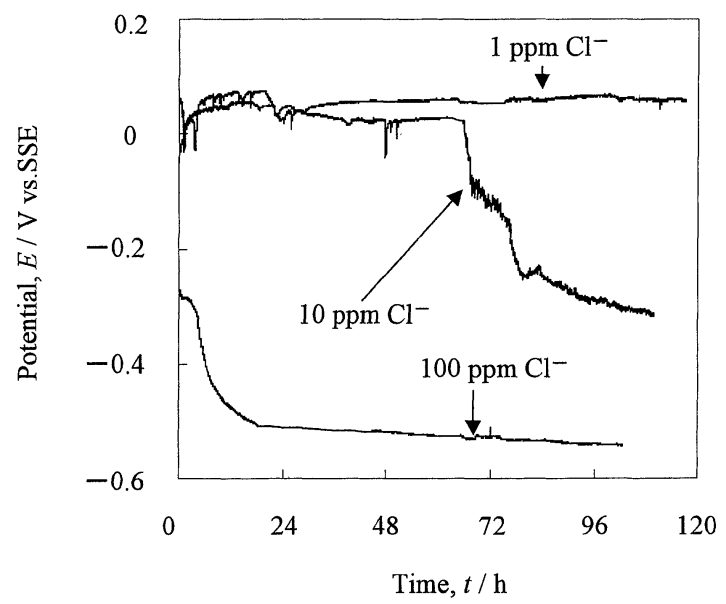

Fig. 12 Potential time series of carbon steel covered with mill scale in aqueous solutions containing $100 \mathrm{ppm} \mathrm{HCO}_{3}$ and 1,10 , and $100 \mathrm{ppm} \mathrm{Cl}^{-}(1 \mathrm{ppm}: \mathrm{pH}=8.0,10 \mathrm{ppm}$ : $\mathrm{pH}=7.8,100 \mathrm{ppm}: \mathrm{pH}=8.0$ ).

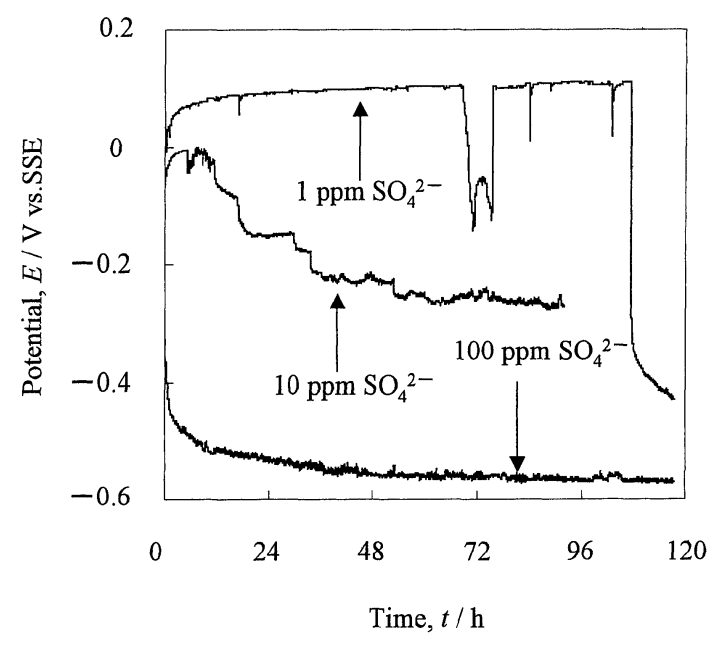

Fig. 13 Potential time series of carbon steel covered with mill scale in aqueous solutions containing $100 \mathrm{ppm} \mathrm{HCO}_{3}$ and 1,10 , and $100 \mathrm{ppm} \mathrm{SO}_{4}{ }^{2-}(1 \mathrm{ppm}: \mathrm{pH}=8.3,10 \mathrm{ppm}$ : $\mathrm{pH}=8.3,100 \mathrm{ppm}: \mathrm{pH}=8.3)$. 
Table 2 Analytical results of the quality of the tap water (Noda-shi, Chiba).

\begin{tabular}{|c|c|c|c|c|c|c|c|}
\hline $\begin{array}{c}\text { Conductivity } \\
(\mathrm{mS} / \mathrm{m})\end{array}$ & $\begin{array}{c}\mathrm{pH} \\
\left(25^{\circ} \mathrm{C}\right)\end{array}$ & $\begin{array}{c}\mathrm{M} \text { alkalinity } \\
(\mathrm{ppm})\end{array}$ & $\begin{array}{c}\text { Total } \\
\text { hardness } \\
(\mathrm{ppm})\end{array}$ & $\begin{array}{c}\text { Calcium } \\
\text { hardness } \\
(\mathrm{ppm})\end{array}$ & $\begin{array}{c}\mathrm{Cl}^{-} \\
(\mathrm{ppm})\end{array}$ & $\begin{array}{c}\mathrm{SiO}_{2} \\
(\mathrm{ppm})\end{array}$ & $\begin{array}{c}\mathrm{SO}_{4}{ }^{2-} \\
(\mathrm{ppm})\end{array}$ \\
\hline 28.4 & 7.5 & 38 & 75 & 53 & 26 & 20 & 41.8 \\
\hline
\end{tabular}

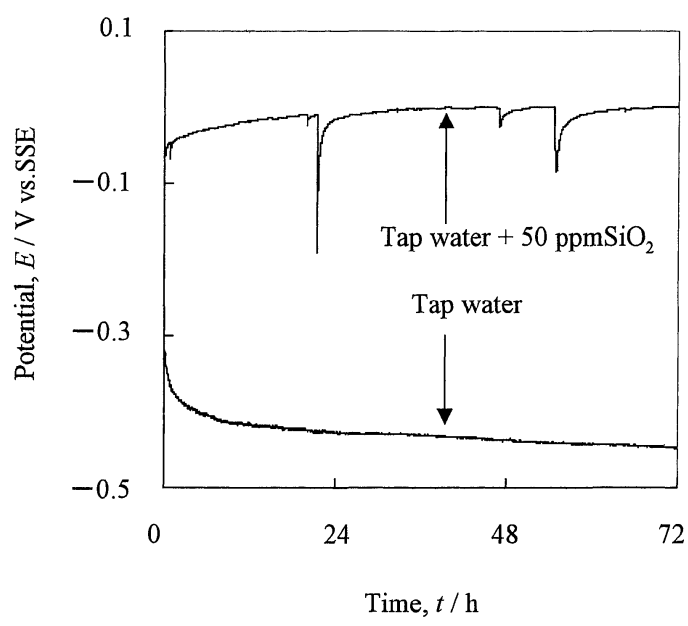

Fig. 14 Potential time series of carbon steel covered with mill scale immersed in tap water (Noda-shi, Chiba) and the tap water involving $50 \mathrm{ppm} \mathrm{Na}_{2} \mathrm{SiO}_{3}(\mathrm{pH}=9.1)$.

\subsubsection{ENA の腐食モニタリングへの適用}

千葉県野田市にある東京理科大学の水道水及び水道水 中に $50 \mathrm{ppm}$ のケイ酸ナトリウムを添加した溶液中に黒 皮付炭素鋼を浸漬させたときの電位経時変化を Fig. 14 に 示す. また Table 2 に水道水中に含まれる成分量及びそ の他特性を載せる. 水道水中での電位は浸漬直後から卑 化し，波形は攻撃性アニオンを含む溶液中でのデータと 類似したものとなった。また浸漬後の試験片表面は全面 的に腐食が生じていた. Table 2 に示したように，本水道 水中の $\mathrm{Cl}^{-}$は $26 \mathrm{ppm}, \mathrm{SO}_{4}{ }^{2-}$ は $41.8 \mathrm{ppm}$ であり, 黒皮を 破壊するためには十分な濃度となっている. 一方, 水道 水中に $50 \mathrm{ppm}$ のケイ酸ナトリウムを添加した場合（溶液 の $\mathrm{pH}$ は 9.5) の電位経時変化には明確な RD 型ノイズが 観察され, 試験後の電極表面には食孔が存在していた。 ケイ酸ナトリウムにより保護皮膜が形成され, 水道水中 の腐食促進性アニオンによる攻撃を受け皮膜破壊が生じ $\mathrm{RD}$ 型ノイズが発生したと考えられる. 以上の水道水中 においても，黒皮付炭素鋼の電位経時変化を測定するこ とにより腐食過程を明らかにできることがわかった。

\section{4. ま と}

ENA を用いて黒皮付炭素鋼の腐食挙動に与える水質因 子の腐食性診断及び黒皮付炭素鋼の腐食発生メカニズム の解明を試みた。 その結果以下に示す知見が得られた。

(1) 様々な溶液中に浸漬した黒皮付炭素鋼の電位経時 変化を測定し, 測定後の電極表面観察結果と関係を比較 した，黒皮が健全である場合は，電極電位は高電位であ り，全面腐食に至ると電位の卑化が見られる。また局部
腐食が発生する場合には電気化学ノイズが観察された。 以上の結果から, 電位経時変化から腐食形態を判定でき, 水質因子の腐食性診断が可能であることがわかった。本 報では試験片として黒皮を有する炭素鋼を用いた。この ように保護性を有する皮膜に覆われている電極を用いる ことで，その皮膜の崩壊過程を追跡することができ，局 部腐食発生の有無を判断できる。しかしながら黒皮は圧 延処理の方法及び条件により性質が変わる．そのため本 法を一般化するためには，標準となる電極表面前処理法 の提案が必要となる.

（2）重炭酸イオンが $100 \mathrm{ppm}$ 程度含む溶液中では黒皮 は安定に存在する，逆に，10 ppm 以下の低濃度の重炭酸 イオンは黒皮の破壊（腐食）を加速する.

（3）中性溶液中では溶性シリカは黒皮付炭素鋼に対し 耐食性を付与せず，アノード反応を促進した。一方，試 験溶液の $\mathrm{pH}$ を上げることにより溶性シリカは耐食性を 付与した。

\section{参 考 文 献}

1) H. Inoue and K. Yamakawa, Electrochemistry, 66, 1076 (1998).

2) R. A. Cottis, M. A. Al-Ansari, G. Bagley and A. Pettiti, Mater. Sci. Forum, 289-292, 741 (1998).

3) F. Mansfeld and H. Xiao, J. Electrochem. Soc., 140, 2205 (1993).

4) J. F. Chen and W. F. Bogaerts, Corros. Sci., 37, 1839 (1995).

5) L. Meszaros, G. Meszaros, A. Pirnat and B. Lengyel, J. Electrochem. Soc., 143, 3597 (1996).

6) F. Mansfeld, C. C. Lee and G. Zhang, Electorochim. Acta, 43, 435 (1998)

7) C. C. Lee and F. Mansfeld, Corros. Sci., 40, 959 (1998).

8) Y. J. Tan, S. Bailey and B. Kinsella, Corrosion, 55, 469 (1999).

9) A. Nagiub and F. Mansfeld, Corros. Sci., 43, 2147 (2001).

10) T. Handa, Y. Miyata and H. Takazawa, Boshoku-Gijutsu (presently Zairyo-to-Kankyo), 38, 529 (1989).

11) T. Tsuru and M. Sakairi, Boshoku-Gijutsu (presently Zairyo-to-Kankyo), 39, 355 (1990).

12) H. Inoue, K. Yamakawa, T. Kikuchi and Y. Yoneda, Zairyoto-Kankyo, 45, 717 (1996).

13) K. Hladky and J. L. Dawson, Corros. Sci., 21, 317 (1981).

14) Y. J. Tan, S. Bailey and B. Kinsella, Corros. Sci., 38, 1681 (1996).

15) Y. F. Cheng, M. Wilmott and J. L. Luo, Corros. Sci., 41, 1245 (1999).

16) F. Mansfeld, Z. Sun and C. H. Hsu, Electorochim. Acta, 46, 3651 (2001).

17) T. Haruna, Y. Morikawa, S. Fujimoto and T. Shibata, Corros. Sci. 45, 2093 (2003).

18) Y. F. Cheng and J. L. Luo, Electorochim. Acta, 44, 4795 (1999).

19) Y. F. Cheng and J. L. Luo, Electorochim. Acta, 44, 2947 (1999).

20) M. Z. Yang, M. Wilmott and J. L. Luo, Corrosion, 54, 869 (1998).

21) T. Mizuno and M. Kitaichi, Electrochemistry, 61, 589 (1993).

22) T. Fukuda and T. Mizuno, Corros. Sci., 38, 1085 (1996). 
23) T. Kodama, J. Jpn. Inst. Met., 21, 666 (1982).

24) S. Takasaki, Reito, 77, 577 (2002).

25) T. Fujii, T. Kodama and H. Baba, Boshoku-Gijutsu (presently Zairyo-to-Kankyo), 31, 637 (1982).

26) M. Yasuda, K. Suzuki and F. Hine, J. Soc. Mater. Sci. Jpn., 32, 1057 (1983).

27) M. Itagaki, Y. Yamada, K. Watanabe, T, Nukaga and F. Umemura, Zairyo-to-Kankyo, 53, 434 (2004).

28) Private discussion with Dr. Masahiro Sakai.

29) JIS, G 02035361

30) JIS, B 01122208

31) K. Soeno, T. Tamamura, K. Akabori, M. Suenaga and M. Tanaka, Hitachi Hyouron, 50, 553 (1968).

32) K. C. Hwang, S. Lee and E. Lee, Tetsu-to-Hagane, 83, 383 (1997).

33) T. Hagyard and J. R. Williams, Trans. Faraday Soc., 57, 2295 (1961).

34) H. S. Isaacs and Y. Ishikawa, J. Electrochem. Soc., 132, 1288 (1985).

35) M. Hashimoto, S. Miyazima and T. Murata, Corros. Sci.,
33, 885 (1992)

36) M. Itagaki, R. Oltra, B. Vuillemin, M. Keddam and H. Takenouti, J. Electrochem. Soc., 144, 64 (1997).

37) D. H. Davies and G. T. Burstein, Corrosion, 36, 416 (1980).

38) E. B. Castro, C. R. Valentini, C. A. Moina, J. R. Vilche and A. J. Arvia, Corros. Sci., 26, 781 (1986).

39) K. Videm and A. M. Koren, Corrosion, 49, 746 (1993).

40) T. Haruna, K. Domoto and T. Shibata, Zairyo-to-Kankyo, 51 $350(2002)$

41) O. Lahondny-Sarc and L. Kastelan, Corros. Sci., 21, 265 (1981).

42) N. Fujita, C. Matsuura and K. Ishigure, Corrosion, 45, 901 (1989).

43) N. Cui, H. Y. Ma, J. L. Luo and S. Choivelli, Electrochem. Comm., 3, 716 (2001).

(Manuscript received April 15, 2004; in final form July 7,2004 )

\section{要旨}

ENA を用いて蒸留水及び様々な成分 $\left(\mathrm{Cl}^{-}, \mathrm{SO}_{4}{ }^{2-}, \mathrm{HCO}_{3}{ }^{-}, \mathrm{SiO}_{2}\right)$ を含む溶液中における黒皮付炭素鋼の 腐食診断及び腐食メカニズム解明を試みた．電位経時変化から腐食形態を判定でき，水質因子の腐食性診 断が可能であることを明らかにした。 $10 \mathrm{ppm}$ 以下の低濃度の重炭酸イオンは炭素鋼の腐食を加速し, 対 照的に $100 \mathrm{ppm}$ 程度の高濃度の重炭酸イオンは黒皮を安定化させることがわかった. 中性溶液中では溶性 シリカは黒皮付炭素鋼に対し耐食性を付与せず，アノード反応を促進した。一方，試験溶液の $\mathrm{pH}$ 上げ ることにより溶性シリカは耐食性を付与した.

キーワード ENA, 炭素鋼, 淡水, 黒皮 